\title{
ABOVE GROUND TREES BIOMASS \\ OF LORE LINDU NATIONAL PARK-CENTRAL SULAWESI : A STUDY COMBINING FIELD MEASUREMENT AND REMOTE SENSING
}

\author{
Naimatu Solicha ${ }^{1}$, Tania June ${ }^{2 *}$, M. Ardiansyah ${ }^{3}$, Antonius B.W ${ }^{4}$ \\ ${ }^{1}$ MIT student, STORMA research grant recipient \\ ${ }^{2}$ Department of Geophysics and Meteorology Bogor Agricultural University, STORMA B1 Counterpart \\ ${ }^{3}$ Faculty of Agriculture Bogor Agricultural University, STORMA D Counterpart \\ ${ }^{4}$ National Coordinating Agency for Surveys and Mapping \\ *Corresponding author. E-mail: Tania.june@yahoo.com
}

Penyerahan Naskah: 18 Januari 2010

Diterima untuk diterbitkan: 26 Mei 2010

\begin{abstract}
Forests play an important role in global carbon cycling, since they hold a large pool of carbon as well as potential carbon sinks and sources to the atmosphere. Accurate estimation of forest biomass is required for greenhouse gas inventories and terrestrial carbon accounting. The information on biomass is essential to assess the total and the annual capacity of forest vigor. Estimation of aboveground biomass is necessary for studying productivity, carbon cycles, nutrient allocation, and fuel accumulation in terrestrial ecosystem. The possibility that above ground forest biomass might be determined from space is a promising alternative to ground-based methods. Remote sensing has opened an effective way to estimate forest biomass and carbon. By the combination of data field measurement and allometric equation, the above ground trees biomass possible to be estimated over the large area. The objectives of this research are: (1) To estimate the above ground tree biomass and carbon stock of forest cover in Lore Lindu National Park by combination of field data observation, allometric equation and multispectral satellite image; (2) to find the equation model between parameter that determines the biomass estimation. The analysis showed that field data observation and satellite image classification influencing much on the accuracy of trees biomass and carbon stock estimation. The forest cover type A and B (natural forest with the minor timber extraction) has the higher biomass than $\mathrm{C}$ and $\mathrm{D}$ (natural forest with the major timber extraction and agro forestry), it is about 607 ton/ha and 603 ton/ha. Forest cover type $\mathrm{C}$ is 457 ton/ha. Forest cover type $\mathrm{D}$ has the lowest biomass is about 203 ton/ha. Natural forest has high biomass, because of the tropical vegetation trees heterogeneity. Forest cover D has the lowest trees biomass because its vegetation component as secondary forest with the homogeneity of cacao plantation. The forest biomass and carbon estimation for each cover type will be useful for the further equation analysis when using the remote sensing technology for estimating the total biomass and for the economic carbon analysis.
\end{abstract}

Keyword: biomass, carbon stock, allometric equation, remote sensing.

\section{INTRODUCTION}

\section{Background}

Forests play an important role in global carbon cycling, since they hold a large pool of carbon as well as potential carbon sinks and sources to the atmosphere. Accurate estimation of forest biomass is required for greenhouse gas inventories and terrestrial carbon accounting (Muukkonen and Heiskanen, 2006).

Lore Lindu National Park, Central Sulawesi, Indonesia is one of the most important protected areas in Indonesia and was declared a "Biosphere Reserve" in 1977. Biosphere reserves were conceived as "experimental sites for sustainable development, research and monitoring on ecosystems and conservation of biodiversity", and are at the same time meant to "promote well being of local people who live in and around the reserve" (UNESCO, 1995). The forest properties will become an important thing to be explored when dealing with the protection effort of the area, and to know the function of the forest for reserving biomass and the carbon pool to the environment. 
Biomass was the name given to any recent organic matter that had been derived from plants as a result of the photosynthetic conversion process. The biomass of forest provides estimates of the carbon pools in forest vegetation because about $50 \%$ of it is carbon. The carbon stock indicates the contribution of forest to carbon cycles related to mitigation of climate change. Direct measurement of biomass on the ground is time consuming (expensive), and repeated measurements, if they occur at all, are generally limited to 10 year interval. Remote sensing has opened an effective way to estimate forest biomass and carbon absoption (Rosenqvist et al., 2003; June et al. 2006). By combining remote sensing technology and empirical model of allometric equation biomass and carbon stock of forest cover area can be estimated with ease.

\section{Objectives}

1. To estimate the above ground tree biomass and carbon stock of forest cover in Lore Lindu National Park by combination of field data observation, allometric equation and multispectral satellite image.

2. To find the equation model between parameter that determines the biomass estimation.

\section{Output}

1. Correlation and Regression equation model of biomass and vegetation indexes, remote sensing biomass and field biomass.

2. Normalized Difference Vegetation Index (NDVI) value using QuickBird satellite image.

3. Per hectare trees biomass derived from different forest cover type and multispectral satellite image classification as the reference to estimate the total biomass and carbon stock in sample plot and whole area.

4. Total trees biomass and carbon stock of whole study area.

\section{METHODOLOGY}

\section{Time and Location}

This research was conducted from FebruaryAugust 2007. The study area is located Toro-Kulawi district of Lore Lindu, Central Sulawesi, Indonesia. Lore Lindu is one of the National Parks in Central Sulawesi, administratively it is belong to Donggala and Posos regency, Central Sulawesi. Geographically lays on $119^{\circ} 58^{\prime}-120^{\circ} 16^{\prime} \mathrm{E}$ and $1^{\circ} 8^{\prime}-1^{\circ} 3^{\prime} \mathrm{N}$.

This research was funded by BMZ and STORMA program. STORMA stand for Stability of Rainforest Margin in Indonesia, is an IndonesianGerman collaborative Research Centre funded by the German Research Foundation (FDG).

\section{Data Source}

There are two main kinds of data using in this research are remote sensing data and field measurement data. The multispectral satellite image data that will be used in this research is QuickBird satellite image with the acquisition date of April, $15^{\text {th }}$ 2004. The main measurement data derived from field are LAI (Leaf Area Index), plant height, diameter breast height, and plant density.

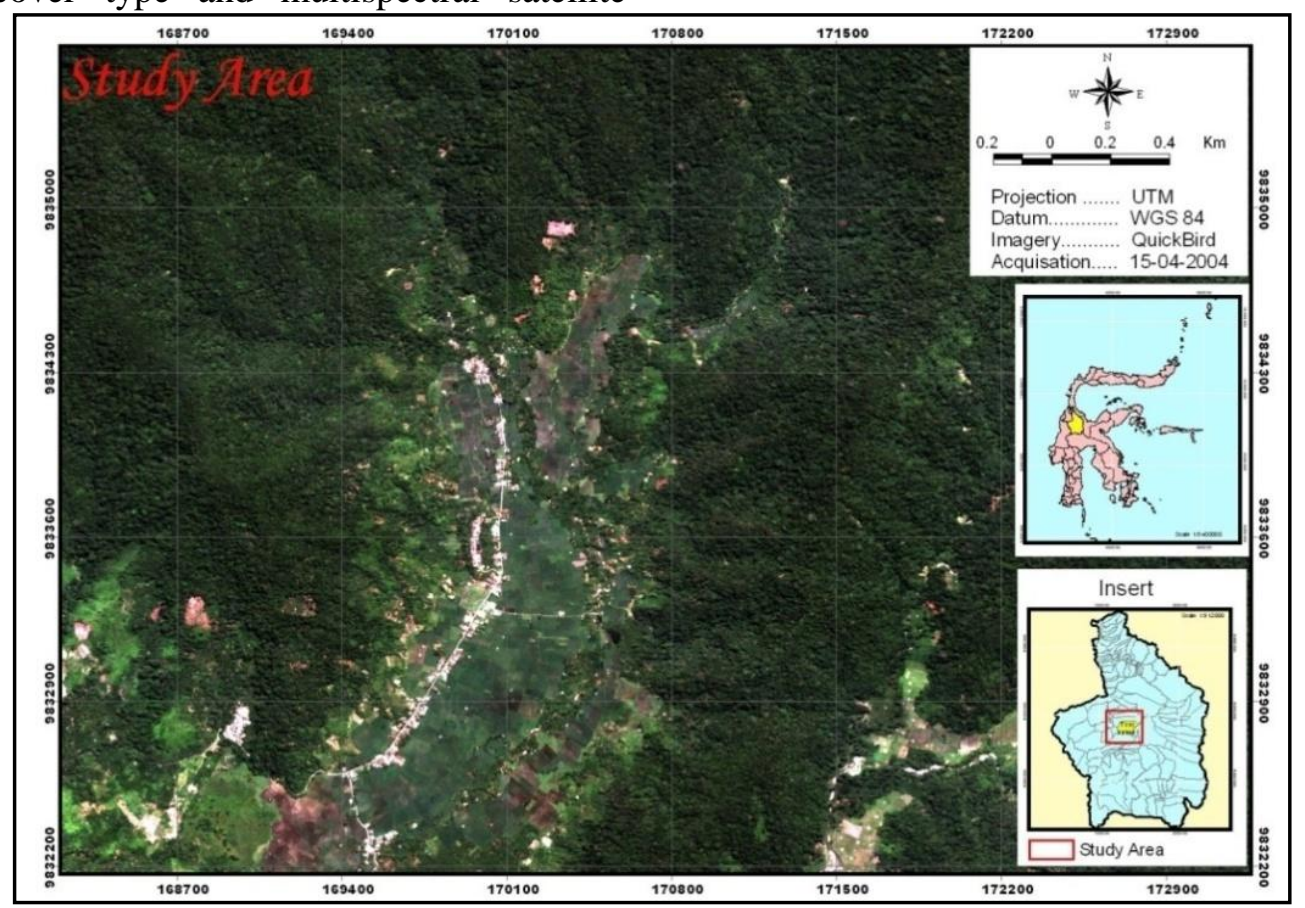

Figure 1 Study Area Location. 


\section{Method}

This research conducted by using the fourth approach as mentioned in literature of estimating the biomass that combines field studies (forest inventory data), analysis of multispectral satellite imagery, allometric equation and statistical analysis. The general procedure is described in Figure 3.

\section{Field Data Measurement}

The selected trees must come from the population of interest, represent the major species in the forest and represent all size classes. The method of field sampling applied for collecting field data is quadrate sampling, with $30 \mathrm{~m} \times 30 \mathrm{~m}$ plot size. The scheme for distributing sample over the area of interest, use stratified systematic random sampling. Stratification done for the forest cover becomes A, $\mathrm{B}, \mathrm{C}, \mathrm{D}$ type (D, E and $\mathrm{F}$ plot grouped into D). Systematic way was chosen to spread the plant in row evenly, and then the trees were measured for each row randomly.

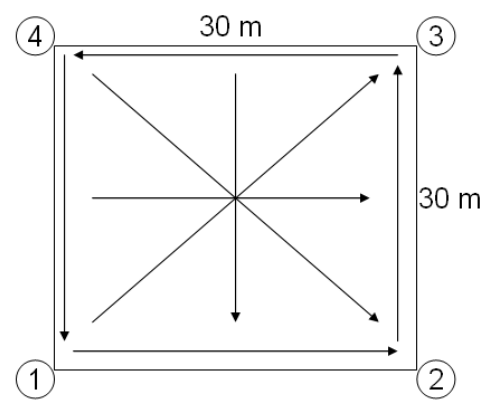

Figure 2 The sampling scheme for field measurement data.

The diameter breast height was measured from the girth of the trees and converted to the trees diameter. Trees total height was measured by using vertex that has the function of measuring heights, distance, angle inclination and air temperature. The $\mathrm{x}$ and $\mathrm{y}$ trees canopy was also measured by using vertex.

Plots observation were based on the forest cover type as defined by STORMA in the second phase (by workshops of 1-9 September 2003) consist of 6 type, these are: Habitat type A, B, C, D, E and F.

Habitat : Natural forest with traditional use type A (rattan extraction) but without timber extraction; closed canopy.

Habitat : Natural with minor extraction of type B small trees (used to build small pondoks) not affecting the closure of the upper canopy layer.

Habitat : Natural forest with major timber type C extraction indicated by large, artificial gaps in and pronounced decrease of the canopy cover to only $40-60 \%$.

Habitat : Agro-forestry system (dominated type $\mathrm{D}$ by cacao) with remaining natural forest trees as shade trees. Canopy closure: $20-50 \%$. Low intensity management.

Habitat : Agro-forestry system (dominated type E by cacao) shaded by diverse spectrum of planted trees and trees naturally grown after clear cutting.

Habitat : Agro-forestry system with a shade type $\mathrm{F} \quad$ tree layer dominated by one tree species (Erythrina) $>90 \%$ of all shade trees belong to one tree species. Canopy closure: $20-50 \%$

[Note: the intensity of the agro forestry management not really differs between habitat types $\mathrm{D}, \mathrm{E}$ and $\mathrm{F}$ in all types crops are more or less planted in rows, so that D, E, and F grouped into D type]

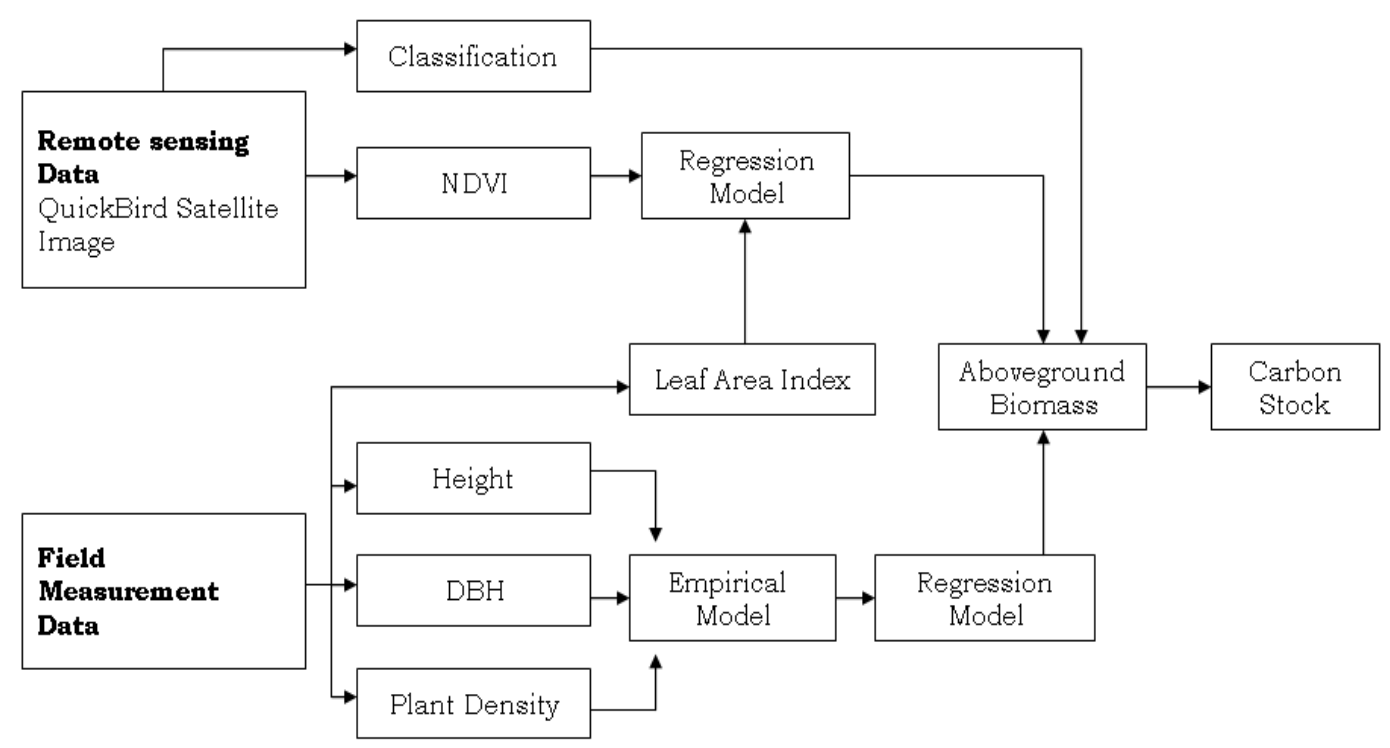

Figure 3 General procedure of biomass and carbon stock estimation. 


\section{Forest covers type classification of QuickBird satellite image}

The classifications for each cover type by using region (training sample set of plot observation) based the different spectral value in each observation plot refer to QuickBird Image.

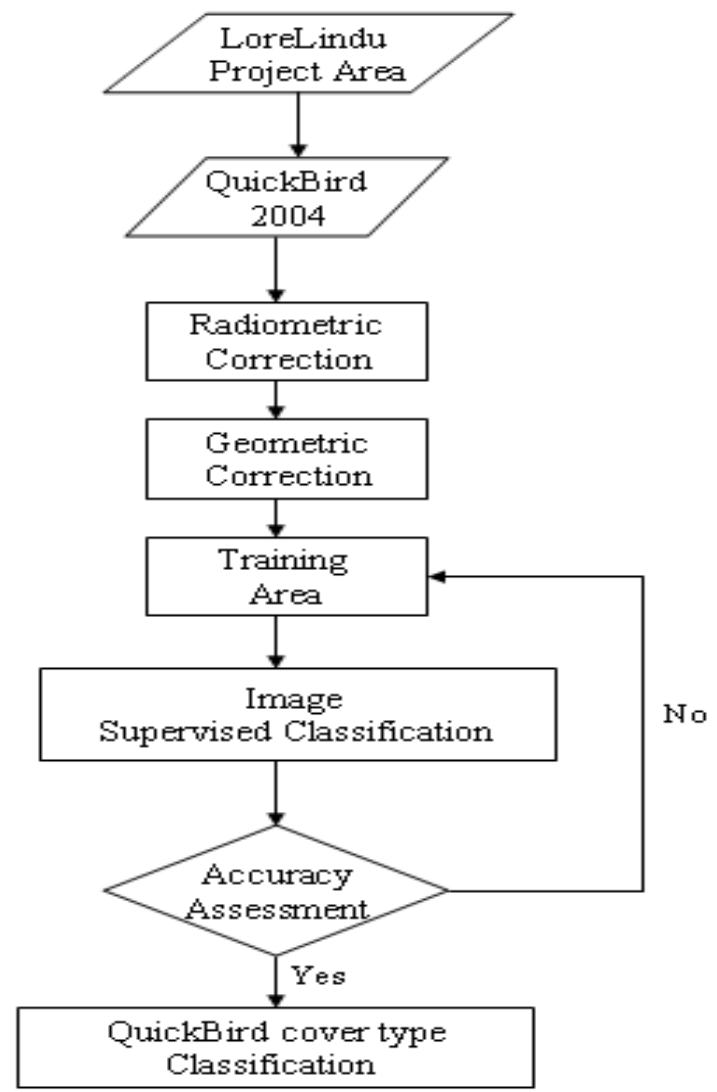

Figure 4 Forest covers type classification procedure.

\section{Calculating Biomass using Allometric Equation (ton/ha)}

The empirical model was chosen to estimate biomass and carbon content by using field data. Empirical model were based on statistical analysis of observed data, and these were usually applicable (derived from previous research).Therefore, the biomass of the tree is estimated with allometric relationship of total height and DBH. Allometric relationship of total height and $\mathrm{DBH}$ will be used to measure quantity of biomass (FAO 1997). To calculate biomass ton per hectare the following allometric equation use Brown, 1997):

$$
W_{d r y}=\exp \left[-3.1141+0.9719 \ln \left(D^{2} H\right)\right] * P / 1000
$$

Where: $\quad \mathrm{W}_{\text {dry }}=$ Total biomass (ton/ha)

$\mathrm{D}=$ Diameter Breast height (cm)

$\mathrm{H} \quad=$ height of plant between blocks (m)

$\mathrm{P} \quad=$ planting density within the blocks

\section{Calculating Carbon-Stock (ton/ha)}

An estimate of carbon stock in plantation is generally based on allometric equations relating as carbon or biomass to plant height. Equation to calculate carbon stock (Winrock 1997):

$$
C-\text { Stock }=0.55 * \text { Biomass }(\text { total })
$$

\section{RESULT AND DISCUSSION}

\section{Field Data Measurement}

The observation sites of each forest cover type is shown in Figure 5. Forest covers A, B, C is natural or primary forest, and forest cover type $\mathrm{D}, \mathrm{E}$ and $\mathrm{F}$ are agro forestry system. Forest cover A has more closed canopy than the other, because there is no timber extraction. Forest cover B still has closed canopy, even with minor extraction of small tress (diameter $<5 \mathrm{~cm}$ ) it has no significant influences on canopy layer. Forest cover $\mathrm{C}$ has less trees and canopy layer than A and $\mathrm{B}$ due to the timber extraction that reduce trees density inside the plot observation. Forest cover D, E and F are agroforestry system that dominated with cacao, because most of the plot observation is cacao plantation that combined with shaded trees.

\section{Forest Cover Type Classification}

The study area of Toro-Kulawi District was chosen for the biomass analysis, because of the consideration about the image data availability that covered this area (Figure 6). Forest cover type classification was conducted by using Supervised Classification of QuickBird satellite image based on region training that utilizes the spectral value of field plot observation. The image was classified into forest and non-forest area. Forest cover type was classified into A, B, C, D and non-forest area (Bare land, shrubs, cloud and paddy field) as depicted in Figure 7. 
Table 1. Plot distribution of field data observation covering NDVI value

\begin{tabular}{cclcc} 
Plot No. & Cover Type & Plot Name & NDVI Value & NDVI Rate \\
\hline 1 & A & South Kalabui & 0.812 & 0.81 \\
2 & A & North Kalabui & 0.821 & \\
3 & A & Lonca & 0.829 & \\
4 & A & Kolewuri & 0.782 & \\
5 & B & Lonca & 0.836 & 0.81 \\
6 & B & Kalabui & 0.827 & \\
7 & B & Kolewuri & 0.779 & \\
8 & C & Komanua & 0.812 & 0.79 \\
9 & C & Kuku & 0.780 & \\
10 & C & Lonca & 0.819 & \\
11 & D & Penga & 0.768 & 0.76 \\
12 & D & Ambi & 0.766 & \\
13 & D & Abia & 0.772 & \\
14 & E & Iskandar & 0.769 & 0.74 \\
15 & E & Ace & 0.685 & \\
16 & E & Abdullah & 0.731 & \\
17 & F & Dada & 0.762 & 0.73 \\
18 & F & Theodoris & 0.770 & \\
19 & F & Andreas & 0.646 & \\
\hline
\end{tabular}

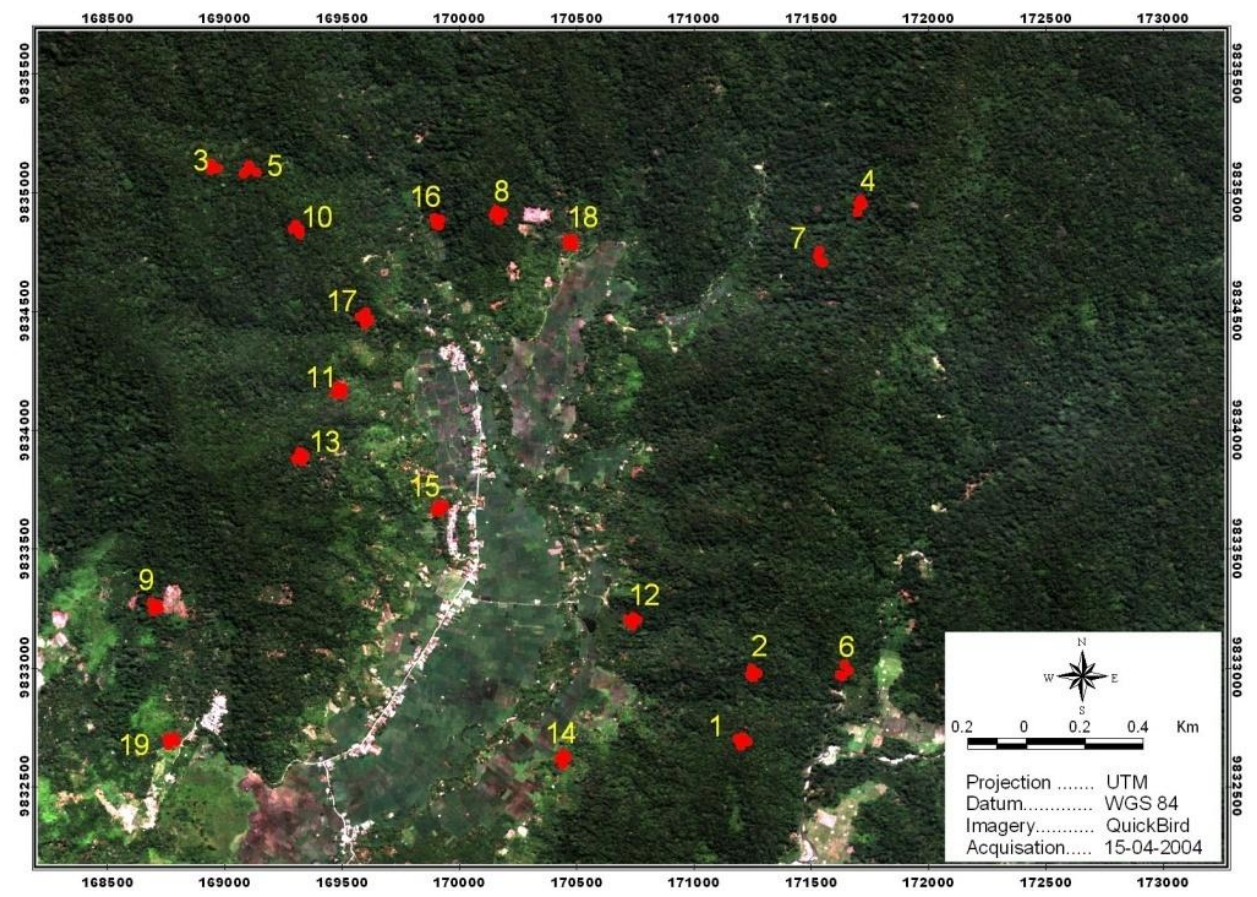

Figure 5 Plot distribution of field data observation. 
Table 2. Percentage of forest and non-forest area in the study site

\begin{tabular}{ccrr}
\hline Area & Type & Total Area (ha) & \multicolumn{1}{c}{$\%$} \\
\hline \multirow{4}{*}{ Forested } & A & 699.04 & 40 \\
& $\mathrm{~B}$ & 525.02 & 30 \\
& $\mathrm{C}$ & 94.53 & 5 \\
Non-forested & D & 119.54 & 7 \\
& Bareland & 28.26 & 2 \\
& Shrubs & 94.41 & 5 \\
& Paddy field & 193.23 & 11 \\
\hline \multicolumn{5}{c}{ Total } & 1754.03 & 100 \\
\hline
\end{tabular}

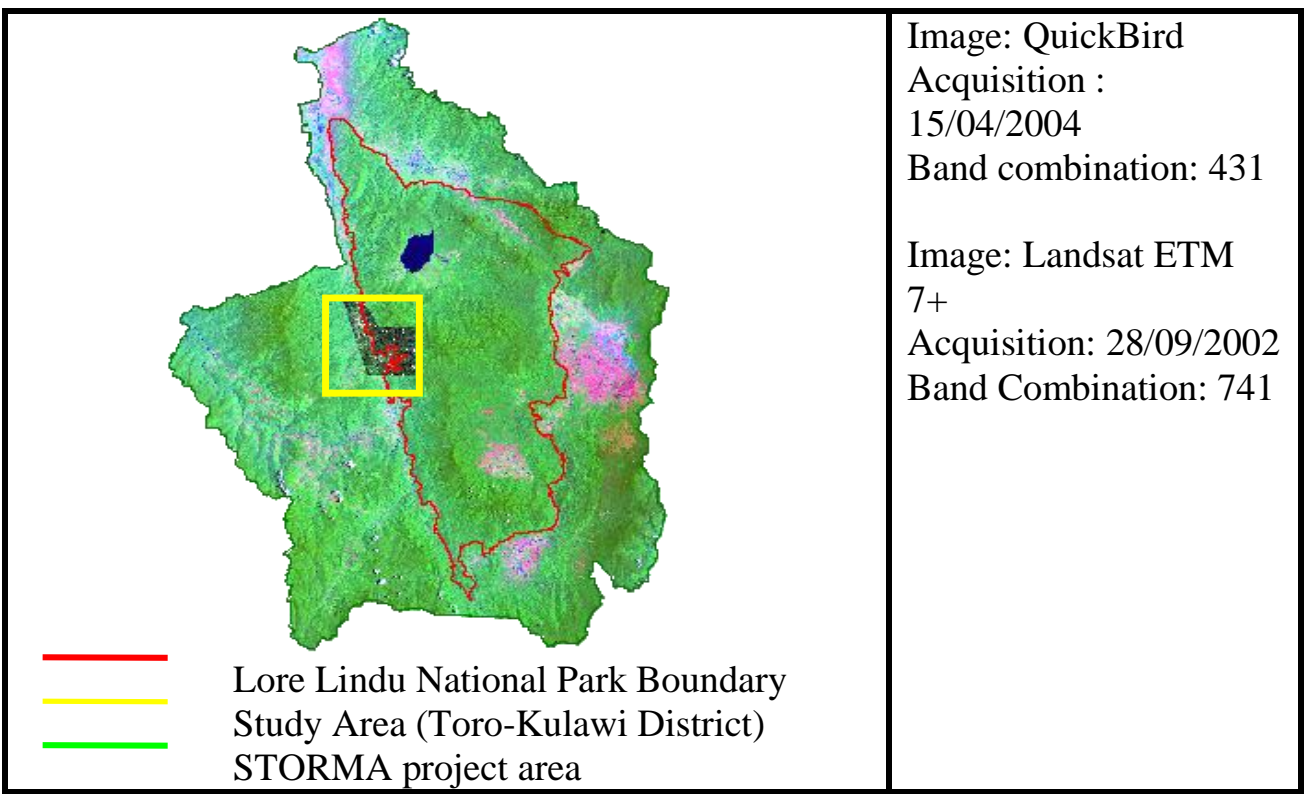

Figure 6 Image of STORMA project area and study area of Toro-Kulawi District.

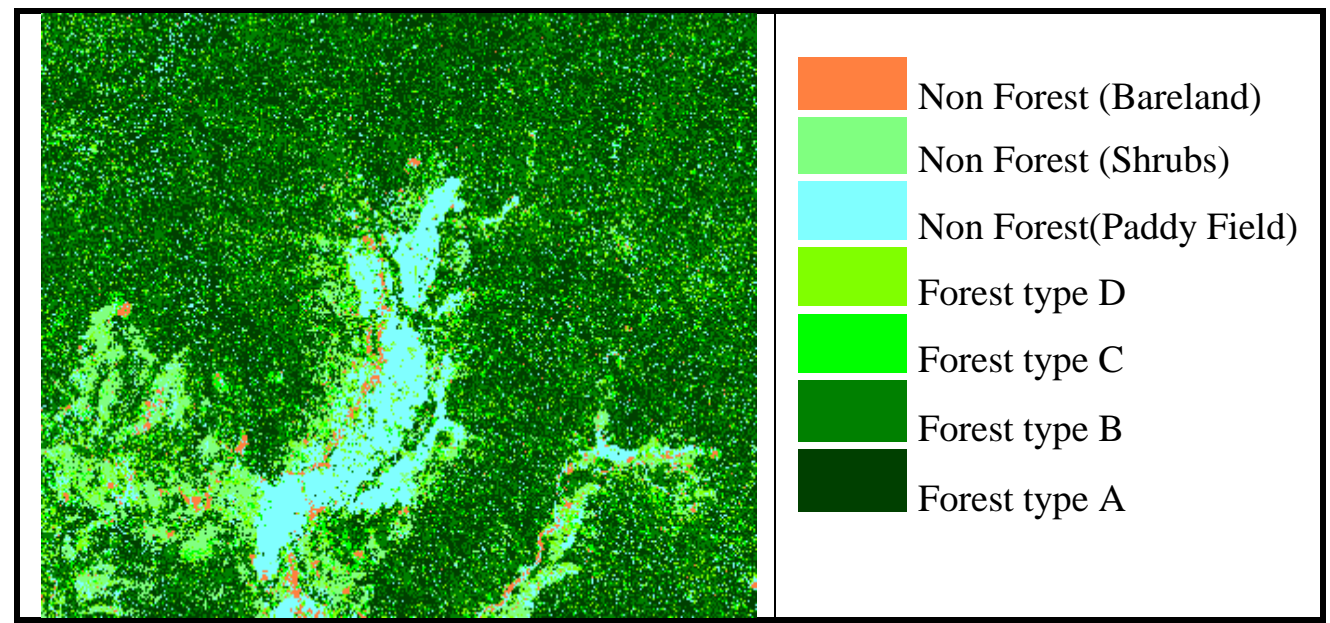

Figure 7 Forest cover classification derived from Quick Bird image.

\section{Regression Model of Forest Cover Type}

The equation models of trees biomass, DBH and height derived from each cover type are summarized in the Table 3. The A, B, C and D forest cover type have different model to estimate the trees biomass. It based on the specific condition of each cover type. The statistical analysis was done by using many sample data (50-70 trees for each cover type) within field plot observation. Each model has different regression coefficient that shows the correlation strength of parameters in the model. The highest regression coefficient has the highest correlation; it means that the model is highly recommended. These models can be applied for estimating biomass in the tropical rain forest with the same condition as mentioned in Table 4. 


\section{Biomass and Carbon Stock Estimation}

Table 3 shows that the trees biomass of each forest cover type is different. The forest cover type $\mathrm{A}$ and $\mathrm{B}$ has the higher biomass than $\mathrm{C}$ and $\mathrm{D}$, it is about 607 ton/ha and 603 ton/ha. Forest cover type $\mathrm{C}$ has 457 ton/ha trees biomass. Forest cover type D has the lowest biomass is about 203 ton/ha. The three high biomass per hectare is belongs to natural forest A, B and C cover type. Natural forest has heterogeneity of tropical vegetation trees that lead to the high biomass. Forest cover D has the lowest biomass because its vegetation component as secondary forest with the homogeneity of cacao plantation.

The total biomass of study area was calculated by multiplying the area in hectare resulted from Quick Bird image classification with biomass per hectare of each forest cover type. The total trees biomass estimation in the study area is 808932 ton, and carbon stock 444912 ton (Table 5).

Table 3. Field trees biomass and C-stock estimation of every plot in each cover type

\begin{tabular}{ccc}
\hline $\begin{array}{c}\text { Forest Cover } \\
\text { Type }\end{array}$ & $\begin{array}{c}\text { Biomass } \\
\text { (ton/ha) }\end{array}$ & $\begin{array}{c}\text { C-Stock } \\
\text { (ton/ha) }\end{array}$ \\
\hline A & 607 & 334 \\
B & 603 & 331 \\
C & 457 & 251 \\
D & 203 & 112 \\
\hline
\end{tabular}

Table 4. Equation model between the parameters

\begin{tabular}{|c|c|c|c|}
\hline Type & Vegetation Type Description & Model & $\mathbf{R}^{2}$ \\
\hline \multirow{5}{*}{ A } & \multirow{5}{*}{$\begin{array}{l}\text { Natural forest with traditional use (rattan extraction) but } \\
\text { without timber extraction; closed canopy }\end{array}$} & $\mathrm{Y}=\log \mathrm{DBH}-1597$ & 0.83 \\
\hline & & $\mathrm{Y}=1.2888 \mathrm{DBH}^{2}-16.508 \mathrm{DBH}+60.506$ & 0.96 \\
\hline & & $\mathrm{Y}=0.0829 \mathrm{DBH}^{2.629}$ & 0.98 \\
\hline & & $\mathrm{Y}=0.0354 \mathrm{TH}^{3.151}$ & 0.88 \\
\hline & & $Y=-1192+125 \mathrm{DBH}-46.4 \mathrm{TH}$ & 0.84 \\
\hline \multirow{6}{*}{ B } & \multirow{6}{*}{$\begin{array}{l}\text { Natural with minor extraction of small trees not affecting } \\
\text { the closure of the upper canopy layer. }\end{array}$} & $\mathrm{Y}=117.37 \mathrm{DBH}-1857.1$ & 0.79 \\
\hline & & $\mathrm{Y}=1.194 \mathrm{DBH}^{2}-11.926 \mathrm{DBH}+9.4608$ & 0.99 \\
\hline & & $\mathrm{Y}=0.0886 \mathrm{DBH}^{2.5909}$ & 0.97 \\
\hline & & $\mathrm{Y}=0.0401 \mathrm{TH}^{3.1412}$ & 0.85 \\
\hline & & $\mathrm{Y}=5.1393 \mathrm{e}^{0.2038 \mathrm{TH}}$ & 0.81 \\
\hline & & $\mathrm{Y}=-863+158 \mathrm{DBH}-120 \mathrm{TH}$ & 0.85 \\
\hline \multirow{4}{*}{$\mathrm{C}$} & \multirow{4}{*}{$\begin{array}{l}\text { Natural forest with major timber extraction indicated by } \\
\text { large, artificial gaps in and pronounced decrease of the } \\
\text { canopy cover to only } 40-60 \% \text {. }\end{array}$} & $\mathrm{Y}=0.1021 \mathrm{DBH}^{2.5478}$ & 0.96 \\
\hline & & $\mathrm{Y}=104.26 \mathrm{TH}-1048.4$ & 0.86 \\
\hline & & $\mathrm{Y}=0.3184 \mathrm{TH}^{2}+53.034^{\mathrm{TH}}-393.45$ & 0.90 \\
\hline & & $\mathrm{Y}=-1223+13.4 \mathrm{DBH}+97.9 \mathrm{TH}$ & 0.86 \\
\hline \multirow{5}{*}{$\mathrm{D}$} & \multirow{5}{*}{$\begin{array}{l}\text { Agroforestry system (dominated by cacao) with } \\
\text { remaining natural forest trees as shade trees. }\end{array}$} & $\mathrm{Y}=104.26 \mathrm{DBH}-1048.4$ & 0.86 \\
\hline & & $\mathrm{Y}=0.3184 \mathrm{DBH}^{2}+53.034 \mathrm{DBH}-393.45$ & 0.90 \\
\hline & & $\mathrm{Y}=0.9688 \mathrm{TH}^{2}+46.49^{\mathrm{TH}}-222.83$ & 0.70 \\
\hline & & $\mathrm{Y}=-416+24.7 \mathrm{DBH}+40.0 \mathrm{TH}$ & 0.76 \\
\hline & & $\mathrm{Y}=0.1475 \mathrm{TH}^{2.8426}$ & 0.75 \\
\hline & \multirow{7}{*}{$\begin{array}{l}\text { Tropical Forest } \\
\text { containing ABCD cover type }\end{array}$} & $\mathrm{Y}=6 \mathrm{E}-05 \mathrm{DBH}^{2.6705}$ & 0.96 \\
\hline & & $\mathrm{Y}=0.0013 \mathrm{DBH}^{2}-0.0159 \mathrm{DBH}+0.0347$ & 0.86 \\
\hline & & $\mathrm{Y}=0.0002 \mathrm{TH}^{2.678}$ & 0.82 \\
\hline & & $\mathrm{Y}=-1.13+0.0701 \mathrm{DBH}+0.0364 \mathrm{TH}$ & 0.67 \\
\hline & & $\mathrm{Y}=33.584 \mathrm{e}^{0.4073 \mathrm{LAI}}$ & 0.59 \\
\hline & & $\mathrm{Y}=0.0065 \mathrm{e}^{13.615 \mathrm{NDVI}}$ & 0.54 \\
\hline & & $\mathrm{LAI}=17.955 \mathrm{NDVI}^{5.3265}$ & 0.67 \\
\hline
\end{tabular}

Note:

Prerequirement model under moist climate $(1500<$ rainfall $<4000 \mathrm{~mm} / \mathrm{year})$ and $\mathrm{DBH}>5 \mathrm{~cm}$

$\mathrm{Y}=$ Biomass $(\mathrm{kg} / \mathrm{plant})$

$\mathrm{DBH}=$ Diameter Breast Height $(\mathrm{cm})$

$\mathrm{TH} \quad=$ Total height $(\mathrm{m})$

LAI $\quad=$ Leaf Area Index

NDVI $=$ Normalized Difference Vegetation Index

To derive biomass in ton/ha= by multiplying biomass with Population in $\mathrm{Ha} / 1000$ 
Table 5. Total trees biomass estimation of study area

\begin{tabular}{crrrr}
\hline Type & $\begin{array}{c}\text { Total Area } \\
(\text { Ha) }\end{array}$ & $\begin{array}{c}\text { Biomass/ha } \\
\text { (ton) }\end{array}$ & $\begin{array}{c}\text { Total Biomass } \\
\text { (ton) }\end{array}$ & \multicolumn{1}{c}{$\begin{array}{c}\text { C-Stock } \\
\text { (ton) }\end{array}$} \\
\hline A & 699.035 & 607 & 424690 & 233579 \\
B & 525.021 & 603 & 316620 & 174141 \\
C & 94.533 & 457 & 43255 & 23790 \\
D & 119.541 & 203 & 24365 & 13401 \\
\hline Total & & & 808932 & 444912 \\
\hline
\end{tabular}

\section{Comparison between research result with other published data}

The estimated above ground trees biomass resulted from the research, especially from cover type A and B is comparable with reported biomass for tropical forest cover before human incursion and with the condition of evergreen high yield in another tropical Asian countries. The above ground trees biomass of forest cover type C 457 ton/ha trees biomass. This estimation biomass value is relatively high if compared with forest cover type $\mathrm{C}$ condition (major timber extraction). This condition equal with the disturbed close, logged hill and evergreen logged forest of another tropical Asian countries that range about 180-255 ton/ha. Forest cover type D has the lowest biomass range about $193-214$ ton/ha.

\section{CONCLUSION}

This research has analyzed the combination of the field data observation, allometric equation, multispectral satellite images classification in estimating the total biomass and carbon stock of the study area. The field data observation influencing much on the accuracy of trees biomass and carbon stock estimation.

The result of the estimation of biomass and carbon from different cover type in Lore Lindu National Park, provide the basic data and information of the losing carbon (carbon stock reduction) as the result of forest cover change into different forest cover type, summarized in this following table.

\begin{tabular}{ccc}
\hline $\begin{array}{c}\text { Forest Cover } \\
\text { Type }\end{array}$ & $\begin{array}{c}\text { Biomass } \\
\text { (ton/ha) }\end{array}$ & $\begin{array}{c}\text { C-Stock } \\
\text { (ton/ha) }\end{array}$ \\
\hline A & 607 & 334 \\
B & 603 & 331 \\
C & 457 & 251 \\
D & 203 & 112 \\
\hline
\end{tabular}

\begin{tabular}{cc}
\hline $\begin{array}{c}\text { Landcover } \\
\text { Changing }\end{array}$ & $\begin{array}{c}\text { C-Stock Reduction } \\
\text { (ton/ha) }\end{array}$ \\
\hline A-B & 2 \\
A-C & 82 \\
A-D & 222 \\
B-C & 80 \\
B-D & 219 \\
C-D & 139 \\
\hline
\end{tabular}

Land cover change could give a significant reduction of terrestrial C-Stock. These significant CStock loss occurred in land cover change from A type become D type (natural forest become cacao plantation) and land cover changing form B type become $\mathrm{D}$ type (natural forest with minor extraction become cacao plantation). Furthermore, this estimation could be worthy information to be brought to the economical and environmental analysis, especially for carbon trading and green house gas inventories due to the recent global warming phenomenon.

\section{REFERENCES}

Adinugroho, W.C. 2002. Model penaksiran biomasa pohon Mahoni (Swietenia macrophylla) di Kesatuan Pemangkuan Hutan Cianjur PT. Perhutani unit III Jawa Barat. Skripsi sarjana Fakultas Kehutanan IPB.

Aldred, A. H. and I. S. Alemdag. 1988. Guidelines for Forest Biomass Inventory. Petawawa National Forestry Inst. Rep. PI-X-77. Canadian Forest Service, Natural Resources Canada, Ottawa.

Asia Pacific Network for Global Change Research. 2000. Land-use Change and Terrestrial Carbon Stocks: Capacity Building, Impacts Assessment and Policy Support in South and Southeast Asia

Brown, S. 1997. Estimating biomass and biomass change of tropical forests. A primer. A forest resources assessment publication. FAO Forestry Paper, 134:1-36

Brown, S. L.P. Schroeder, and J. S. Kern.1999. Spatial distribution of biomass in forests of the eastern USA. For. Ecol. Manage., 123-81-90. Available: http://www.sciencedirect.com/science 
Brown, S., Gillespie, A. J. R., Lugo, A. E. 1991.Biomass of tropical forests of South and Southeast Asia, Can. For Res., 21: 111-117.

Brown, S., Iverson, L. I., Prassad A. 1993.Geographical distribution of carbon in biomass and soils of tropical Asian forests, Geocarto International, 4: 45-59.

Brown, S.L., and A.E. Lugo.1984. Biomass of tropical forests: a new estimate based on forest volume. Science, 223:1290-1293.

Chen and Cihlar. 1995. Quantifying the effect of canopy architecture on optical measurements of leaf area index using two gap size analysis methods. IEEE Trans. Geosci. Remote Sensing Environment., 33: 777-787

Congalton, G. Russell and Green, Kass. 1999. Assessing the accuracy of remote sensed data: Principles and practices. Lewis publishers.

Curran, P. J., J.Duncan, and H.L.Gholz.1992. Seasonal LAI Measurement in slash pine using Landsat TM. Rem. Sensing Environ., 39:3-13.

Czaplewski, R.L.1999. Multistage remote sensing: toward an annual National Inventory. J. For., 97: 44-48.

Data dan Informasi Kehutanan Propinsi Sulawesi Tengah. 2002. Pusat Inventarisasi dan Statistik Kehutanan. Badan Planologi Kehutanan

Fang J., G. Wang. G. Liu, and S. Xu.1998. Forest biomass of China: an estimates based on the biomassvolume relationship. Ecol. Appl., 8: 1084-1091.

FAO Corporate Document Repository. Assessing carbon stocks and modeling win-win scenarios of carbon sequestration. Available: http://www.fao.org/docrep/007/y5490e/y5490e07.h $\underline{\mathrm{tm}}$

Fassnacht. K.S., S.T. Gower, J.M. Norman, and R.E. McMurtrie.1994.A comparison of optical and direct methods for estimating foliage surface area index in forests. Agric. For. Meteorol., 71:183-207

Fournier, R. A., J. Luther, M. Wulder, C.H. Ung, S. Magnussen, L. Guindon, M.C. Lambert and J.
Beaubien.1999. Mapping forest biomass from inventory and remotely sensed data. Pages 171-178 in vol II. Proc. $21^{\text {st }}$ Can. Symp. Rem. Sensing. Canadian Aeronautics and Space Institute. Ottawa.

Franklin, E. Steven. 2001. Remote Sensing for Sustainable Forest Management. Lewis Publishers. USA.

Hairiah, et al., 2003. Bahan ajar agroforestry. Fungsi dan peran agroforestry. ICRAF. Bogor Indonesia.

Hairiah et al., 2001. Lecture Note 4A. Carbon stock of tropical land use systems as part of the global $\mathrm{C}$ balance: effect of forest conversion and option for 'clean development' activities. ICRAF. Bogor Indonesia.

Hairiah, K., Sitompul, S. M., Assessment and simulation of aboveground and belowground $\mathrm{C}$ stocks and dynamics, Bogor, Indonesia, Science and Policy Workshop on Terrestrial Carbon and Possible Trading under the CDM, IC-SEA, BIOTROP, 27 February-1 March, 2000.

Houghton, J. T., Meira Filho, L. G., Lim, B. eds. 1997. Greenhouse Gas Inventory Workbook, Paris: Intergovernmental Panel on Climate Change (IPCC), Organization for Economic Co-operation and Development (OECD) and the International Energy Agency (IEA), 5.1-5.54.

Houghton, R. A. 1991. Release of carbon to the atmosphere from degradation of forests in tropical Asia, Can. J. For Res., 21: 132-142.

Htut, Moe Tin. 2004. Combination between empirical modeling and remote sensing technology in estimating biomass and C-stock of oil palm in Salim Indoplantation Riau Province. MIT-IPB Thesis. Bogor.

June. T., Ibrom, A. \& Gravenhorst, G. 2006. Integration of NPP Semi Mechanistic Modeling, Remote sensing and GIS in Estimating $\mathrm{CO} 2$ absoption of Forest Vegetation in Lore Lindu National Park.BIOTROPIA, The Southeast Asian Journal of Tropical Biology, 13 (1): 22-36. 